\title{
PATTERN OF VAGINAL DISCHARGE IN PREGNANT FEMALES:- A CLINICOPATHOLOGICAL STUDY
}

\section{Obstetrics \& Gynaecology}

Dr. Akriti Prasad* Senior Resident, Department of Obstetrics and Gynaecology, Nalanda Medical college and Hospital, Patna, Bihar. *Corresponding Author

\section{ABSTRACT}

Introduction: Normal vaginal discharge during pregnancy is called leukorrhea and is thin, white, milky and mild smelling. Pathological vaginal discharge in pregnant females can cause serious illness to pregnant female and her newborn baby.

Aims and objective: To determine the prevalence, pattern and risk factors associated with clinicopathological discharge and its complications.

Materials And Methods: This Prospective study was done over a period of 6 months from September 2019 to February 2020 on 100 pregnant females with vaginal discharge attending OPD in department of obstetrics and gynaecology, Nalanda Medical college and Hospital, Patna, Bihar. Result: 100 pregnant females attending antenatal clinic with vaginal discharge were included in this study. Out of 100 pregnant females, 60(60\%) were primigravida while $40(40 \%)$ were multigravida. $80(80 \%)$ of females were asymptomatic while $20(20 \%)$ were symptomatic. Out of $20(20 \%)$ Symptomatic females, 16(80\%) were having vaginal candidiasis while, 4(20\%) had Bacterial vaginosis. Among 20(20\%) symptomatic patients, $5(25 \%)$ developed Threatened Preterm, 4(20\%) developed Premature Rupture of Membrane (PROM), 1(5\%) Preterm delivery, while 10(50\%) shows no complications during pregnancy and its outcome.

Conclusion: This Prospective study concludes that timely detection and intervention can prevent complications like threatened preterm, PROM, prematurity among symptomatic pregnant females.

\section{KEYWORDS}

\section{INTRODUCTION}

Pregnancy causes changes in vaginal discharge, which can vary in colour, texture and volume. An increase in vaginal discharge is often one of the earliest signs of pregnancy. Some changes in colour are also normal, while others may indicate infection or another problem.

Most pregnant women have vaginal discharge that are either physiological or pathological. Infectious vaginitis is usually caused by yeast such as Trichomonas, Chlamydia, mycoplasma, Group B Streptococcus or herpes. The challenge of treating vaginitis in pregnancy is the necessity of making accurate diagnosis and treating correctly. Infection with Bacterial vaginosis, Chlymadia or Group B streptococcus has been associated with septic abortion, PROM and Premature delivery. Asymptomatic colonisation requires no treatment. Hence, screening is not required routinely. However, symptomatic patients require prompt intervention and treatment.

\section{AIMS \& OBJECTIVES}

To determine the prevalence, pattern and risk factors associated with clinicopathological discharge and its complications.

\section{MATERIALS \& METHODS}

This was a prospective study done over a time period of 6 months between September 2019 to February 2020. This study includes 100 pregnant females attending antenatal clinic at department of obstetrics and gynaecology, Nalanda Medical college and Hospital, Patna, Bihar.

\section{Patients evaluated with following}

1. Clinical history and examination

2. Blood investigation such as complete blood count, RBS and Routine examination of urine

3. High vaginal swab for culture and sensitivity

\section{RESULT}

100 pregnant females with vaginal discharge were studied. $80(80 \%)$ of females were asymptomatic while 20(20\%) symptomatic.

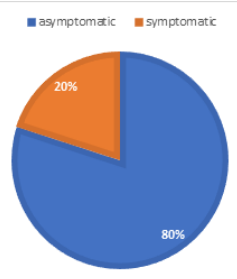

Fig.1

Out of 100 pregnant females, $60(60 \%)$ were Primigravida, while $40(40 \%)$ were Multigravida. Maximum numbers of symptomatic females belong to younger age group i.e. below 25 years.

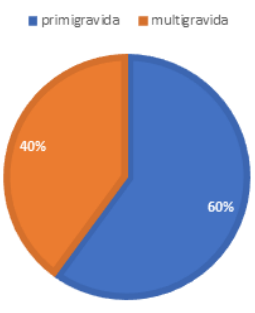

Fig 2

Out of 100 females, 70 females were from low socioeconomic status, 38 were having anaemia, 15 having urinary tract infection and 3 were diabetic.

Table.1

\begin{tabular}{|l|l|}
\hline Risk factors & No. of Pregnant women \\
\hline Low socioeconomic status & 70 \\
\hline Anaemia & 38 \\
\hline Urinary tract infection & 15 \\
\hline Diabetes & 3 \\
\hline
\end{tabular}

Out of 20(20\%) symptomatic pregnant females, $16(80 \%)$ had Vaginal candidiasis, while $4(20 \%)$ had Bacterial Vaginosis.

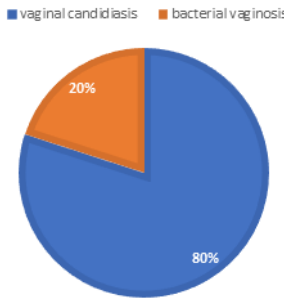

Fig 3

Out of 20 symptomatic patients, $5(25 \%)$ developed Threatened preterm, 4(20\%) PROM, 1(5\%) Preterm delivery, while 10(50\%) shows no complications.

\section{DISCUSSION}

In this study, $20 \%$ of pregnant females were symptomatic. Primigravida were affected more than multigravida. Low socioeconomic status, UTI, anaemia and diabetes were risk factors. Hence, timely detection and prompt treatment helps to avoid maternal and perinatal morbidity and improves pregnancy outcome.

A study by Fonseca et al in 2008 showed higher prevalence of vaginal 
discharge in younger pregnant women. This study correlates with my study which also shows high prevalence in younger patients as compared to older one [1].

Cesar at el (2009) found higher rates of vaginal discharge during pregnancy among poor women. Similar result was found in this study, where low socioeconomic status affects health of the patients [2].

Anaemia was significantly associated with vaginal discharge during pregnancy. Half of the women who had anaemia reported pathological vaginal discharge. This finding corroborated by another study done by Ayoya MA et al in 2006 [3].

Threatened premature labour, PROM, Preterm delivery were associated with pathological vaginal discharge. STIs have been associated with adverse pregnancy outcomes including Premature birth and low birth weight- both major determinants of infant morbidity and mortality especially in developing countries where neonatal intensive care is available in very few centres $[4,5]$.

Primigravida women of low socioeconomic status are more likely to have vaginal discharge. These stresses need for proper management and treatment of vaginal discharge. The high prevalence observed in this study of infections such candidiasis, Bacterial vaginosis in pregnant female emphasizes the need to adopt effective strategies for the need to adopt effective detection and treatment. Educations regarding good hygiene and habits can prevent serious comorbid conditions.

\section{CONCLUSION}

Pathological vaginal discharge in pregnant females is found to be more prevalent in younger age group and primigravida patients. Low socioeconomic status, UTI, anaemia and diabetes have been found to be high risk factors for pathological vaginal discharge. Threatened premature labour, PROM, Preterm delivery strongly associates with pathological vaginal discharge. This study concludes need for timely detection and advise on good personal hygiene and intervention in form of medical treatment and prevention of complications.

\section{REFERENCES}

1. Fonseca TMV, Cesar JA, Hackenhaar AA, Ulmi EF, Neumann NA. Corrinento vaginal referido entre gestantes em localidade urbana no sul do brasil: Prevalenia e fatores referido entre gestantes em localidade urbana no sul do brasil: P
associades cadernos de saude publica. 2008;24: 558-556 (PubMed)

2. Cesar JA, Mendaz Sassi RA, Gonzalez chica DA, et al. Prevalencia e falores associates a perpao de occurrencia de corrimento vaginal patologica entr gestantes. Cadernos de sauce publica. 2009; 25:2705-2714 (PubMed)

3. Ayoya MA, Spiekermann Brouwer GM, Traore AK, Stoltzffus RJ, Garza C. Determinans of anaemia among pregnant women in mali. Food and nutrition bulletin. 2006;27(1):3-11 (PubMed)

4. Da silveria MF, Santosis, Barros AJD, Matijasevich A, Barros FC, Victoria CG. Increase in preterm bith in brazil: review of population base studies. Revista de saude Publica. 2008; 42: 957-964 (PubMed)

5. Lajos GJ, Passini R, JR, Nomura ML, et al cervical bacterial colonization in women with preterm labour or PROM. Reverta brasiliena de ginecologia and obstetrician. 2008; 30(8): 393-399(PubMed) 